\title{
Policy, Youth Recruitment and Empowerment in Nigeria: A Case Study of Osun State Youth Empowerment Scheme (OYES)
}

Badejo B.T.

\author{
Department of Local Government Studies
}

Agunyai S. C.

Department of Political Science

Adeyemi, 0. 0.

Department of Local Government Studies, Obafemi Awolowo University lle-Ife, Osun State, Nigeria Email: funktob@gmail.com

\section{Doi:10.5901/mjss.2015.v6n1s1p384}

Abstract

This study examines the effect of Osun State Youth empowerment Scheme (OYES) on job creation and youth empowerment in the state and appraised its impact on capacity building of the youth. It also identified challenges in its implementation in the state. These were with a view to identifying gap between its expected outcomes and its achievements. Data for this study were generated through primary and secondary sources of data collection. The primary source of data includes a structured questionnaire and interview conducted among unemployed beneficiaries and OYES coordinators/inspectors. The secondary source of data includes books, journals, newspapers, periodicals, and internet materials. Quantitative data were analysed using univariate and bivariate analysis (chi-square test), while content analysis was employed for qualitative data. The results showed that $84 \%$ of the respondents were of the view that OYES was just a palliative measure that has helped to create few jobs and empowered youths in the state. It was also indicated by $57 \%$ of the respondents that the capacity building of youths was not improved because OYES scheme was more focused on unskilled menial jobs. In addition, $85 \%$ of the respondents were of the view that the implementation of OYES was faulty with challenges. The study concluded that there was gap between expected outcomes of OYES and its achievements so far in the Osun State.

Keywords: Empowerment, OYES, Public Policy, Youth, National Development

\section{Introduction}

Intellectual discourse and research in public policy, particularly in respect of youth empowerment, is engendered mainly by policy failures caused by lack of political will, corruption and negligence on the part of government to harness the potentials of the youth among other things. Youth unemployment has thus provoked studies aimed at resolving this menace given the immense role that can be played in the country's national development drive by the youth. In Nigeria, and Osun State in particular, policies have been enunciated and implemented in a bid to correct certain perceived neglect of youths in terms of gainful employment by previous administration in the state. Of all government policies deliberately put in place to address problems of unemployment among youths in Osun through affirmative action, the policy of Osun State Youth Empowerment Scheme (OYES) occupies a pride of place but there is the need to assess it to identify if there is gap between its expected end and what it's achievements so far in Osun State.

The foregoing notwithstanding, not much intellectual resources have been deployed to assessing OYES policy as a vehicle for job creation and youths' recruitment in Osun State Civil Service as well as tool for youths empowerment. The basic issue to which this study addresses itself is to, in an exploratory manner; assess OYES within the context of youth's recruitment, skills acquisition, empowerment and challenges in its implementation. However, the study is interested in knowing if jobs are created, youths are recruited and empowered with the implementation of OYES. If yes, to what extent, if at all, has it been properly implemented? If not, what options are available to government? While this paper does not claim to provide exhaustive analyses to all these questions, it will attempt to properly assess the impact of OYES policy on job creation, youth recruitment and empowerment in the state. 


\section{Research Problem, Aim and Objectives}

The Government of Osun State since 2010, has formulated and implemented a policy tagged OYES (Osun State Youth Empowerment Scheme), to harness the potentials of the youth and address the problem of unemployment. While similar patterns of this scheme have been formulated by past successive governments of the state, much of these schemes if not all, have failed to achieve their expected outcomes. Therefore, it is necessary to assess OYES and identify gap between its expected outcomes and achievements so far in Osun State, hence the study.

The aim of this study is to examine the relationship between OYES and youth recruitment and empowerment in Osun State. The specific objectives of the study are to

1. examine the effect of OYES on reduction of youth unemployment and empowerment in Osun State;

2. appraise the impact of OYES on capacity building of the Youth in Osun State ; and

3. identify challenges in the implementation of OYES in Osun State.

\section{Research Questions}

The study seeks to provide answers to the following research questions:

1. What is the effect of OYES on job creation and skills acquisition in Osun State?

2. What is the impact of OYES on youth's capacity building in Osun State?

3. What are the challenges encountered in the implementation of OYES in Osun State?

\section{Research Hypotheses}

In quest of providing answers to the basic questions itemized above, the following hypotheses which are stated in their null form were tested in this research work:

i. There is no relationship between the implementation of OYES policy and job creation in Osun State

ii. There is no significant relationship between implementation of OYES and youth capacity building in Osun State.

\section{Conceptual and Theoretical Frameworks}

Studies have established that there is positive relationship between job creation, and empowerment of the segment of the population through policies or schemes of groups which include women, youths and the poor (Oluremi and Agboola 2011; Carter and Wilton, 2006). Public policy is government actions or inactions. It is a programme designed to tackle certain issue in a society. It is the formulation of what is to be done by government, whether it is actually done or not is a policy. This implies that policy is not necessary need to be implemented, it is just an expression or statement of government actions or inactions over prevailing issue in the society. It is important to note that OYES as matter of fact can be regarded as public policy or palliative measure designed to address certain perceived problems of unemployment, poverty and low capacity of youths in Osun State.

Youth empowerment is a process whereby young people gain the ability and authority to make decisions and implement change in their own lives (Agary, 2013). For instance, youths in Osun State who are trained in the art of moulding blocks, repairing laptops, electronic gadgets on the platform of government programme or scheme are empowered by gaining requisite skills that will in the long run make them self-reliance.

Capacity building in the context of development implies a dynamic process which enables individuals and agencies to develop the critical social and technical capacities to identify and analyse problems as well as proffer solutions to them. Also, Azikiwe (2006a) defines capacity building as the process by which an individual, irrespective of sex, are equipped with skills and knowledge they need to perform effectively and efficiently in their different callings. For instance, capacity building of youths in Osun State was fairly improved through ICTs, technical vocation learning of the OYES programme.

\section{Theoretical Framework}

The study is anchored on elite theory, which is of the view that political power resides in a few in the society while the majority are led. Elites, according to the proponents of the theory Gaetano (1939), Michels (1942) have features as wealth, intelligence, special skills, moral character, and hosts of others. The theory holds the view that the society is made of two classes the higher stratum, the elite that is further divided into the ruling class or governing and non- 
governing elite, and a lower stratum or non-elite. The connection of this theory to explaining effect of (OYES) on job creation and empowerment of youths in Osun State essentially lies within the context of the role of elites in policy making. Policy makers in their own rights, are elites. Incidentally, they often tend to reflect their values and preferences as they formulate policies. Corroborating this view, Ayinde (2008), averred that "only a matter of coincidence if the policy decisions of the elite reflect the interests of the masses", as they sometime do. For instance in Osun State, the OYES policy to a reasonable extent has reflected interests of the masses as large chunk of activities in the scheme is service and rural based.

\section{Evolution of Osun Youth Empowerment Scheme (OYES) in Osun State}

OYES is a grassroots driven youth empowerment scheme that seeks to direct the bursting energy of this army of unemployed youth towards the good of the society. The scheme was inaugurated in 2010 by Governor Rauf Aregbesola where he declared to engage 20,000 youths across the state in a blend of community service and social welfare models. Osun Youth Empowerment Scheme (OYES) is a strategic youth's management for social support operation in public work fare. It is a revolving volunteer's scheme designed to eliminate the frustrating and paralyzing effects of youth unemployment in the Osun State, Nigeria. It aims at empowering youths by equipping them with positive work ethics and culture, thus making them employable or employers of labour, with respect for the environment. It is designed to develop youths with Character, Innovation and Competence (the $\mathrm{CIC}$ ); infusing them with honour and integrity in life (Ifaturoti, 2013).

The OYES scheme also runs a community service in the state. Community service is the core of the empowerment scheme. Through various work cadres such as; The Green Gang, The Sanitation Czars, The Paramedics, The Traffic Marshalls, The Sheriffs, The Teachers Corp and the Public works gang, the volunteers render selfless services to their communities (Ifaturoti, 2013). The scheme also has a concise skills development component, to arm the volunteers with the functional skills to prosecute a productive life once they exit the scheme. The state government has independently or through partnerships executed various training programmes to support the OYES volunteers. Notable among these are:

- OYESTECH: Training of 5000 youths on Mobile and Computer Support and Production.

- OYES SHOES: Leather Shoes Craftmanship.

- OREAP Academy: Agriculture Entreprenuership Programme.

- Osun Land Enumerations Programme.

- O Red Brick: Red Brick Technology acquisition programme.

\section{Methodology}

Data for this study were generated through primary and secondary sources of data collection. The primary source of data include a structured questionnaire and interview conducted among unemployed beneficiaries, coordinators and officers from regulatory body such as State Economic Empowerment Development Strategies (SEEDS).The reason for this selection was based on the fact that some of these key informants are beneficiaries of the scheme while others have had adequate knowledge of how previous or new empowerment scheme operates in the state. For quantitative method of data collection, 45 people from each district were interviewed using structured questionnaire. While for the qualitative method of data collection an interview guide (unstructured) was used to interview the remaining 3 other key informants drawn on senatorial district basis. The secondary source of data include books, journals, newspapers, periodicals, and internet materials. The quantitative data was analysed using Statistical Package for Social Sciences (SPSS) version 17, univariate and bivariate analysis (chi-square test) was employed. Content analysis was used to analyse the qualitative data.

\section{Background Characteristics of Respondents}

This section presents the univariate analysis of data. The section discusses the socioeconomic and demographic characteristics of the sampled respondents. The discussion of background characteristics of the respondents is essential for survey findings on the policy analysis of Osun State Youth Empowerment Scheme. The univariate analysis also entails the percentage distribution, graphical analysis of other relevant variables with regard to the objectives of the study. 
Table 1: Percentage Distribution of Respondents by Socioeconomic and Demographic Characteristics

\begin{tabular}{|c|c|c|}
\hline Variable & Frequency & $(\%)$ \\
\hline \multicolumn{3}{|l|}{ Sex } \\
\hline Male & 72 & 53.3 \\
\hline Female & 63 & 46.7 \\
\hline Total & 135 & 100.0 \\
\hline \multicolumn{3}{|c|}{ Age } \\
\hline $20-30$ & 96 & 71.1 \\
\hline $31-40$ & 30 & 22.2 \\
\hline $41-50$ & 9 & 6.7 \\
\hline Total & 135 & 100.0 \\
\hline \multicolumn{3}{|l|}{ Occupation } \\
\hline Employed & 17 & 12.6 \\
\hline Unemployed & 72 & 53.3 \\
\hline Self employed & 46 & 34.1 \\
\hline Total & 135 & 100.0 \\
\hline \multicolumn{3}{|c|}{ Religion } \\
\hline Christianity & 109 & 80.7 \\
\hline Islam & 26 & 19.3 \\
\hline Total & 135 & 100.0 \\
\hline \multicolumn{3}{|c|}{ Educational level } \\
\hline Secondary & 42 & 31.1 \\
\hline Undergraduate & 84 & 62.2 \\
\hline Postgraduate & 9 & 6.7 \\
\hline Total & 135 & 100.0 \\
\hline
\end{tabular}

(Source: Field Survey, 2014)

Table 1 shows the percentage distribution of respondents, both male and female are in equal proportion (male, 53.3\%; female, 46.7\%). As regards age, an important demographic variable, a huge proportion (71.1\%) is within the age group "20-30", one - fourth are in the age category "31-40" and a handful of the respondents (6.7\%) are within the age bracket "41-50". Concerning occupation, more than half of the respondents (53.3\%) are unemployed; more than a third (34.1\%) are self -employed and (12.6\%) are unemployed. In addition to this, a substantial proportion are Christian faithful (80.7\%) while less than one-fifth (19.3\%) are Islam faithful. Regarding educational level of the respondents, almost two - thirds (62.2\%) are undergraduate/graduate; more than one-third are secondary school graduate (31.1\%) and a handful are postgraduate students (6.7\%).

Table 2: Respondents views on impact of OYES on Youth's Unemployment, Capacity Building and skills acquisition.

\begin{tabular}{|c|c|c|}
\hline OYES has significantly improved Youths capacity building in Osun State. & Frequency & (\%) \\
\hline Strongly agree & - & - \\
\hline Agree & 7 & 5.1 \\
\hline Strongly Disagree & 18 & 13.1 \\
\hline Disagree & 60 & 43.8 \\
\hline Undecided & 50 & 38.0 \\
\hline Total & 135 & 100.0 \\
\hline Implementation of the scheme is flawed with challenges and implementation gap & & \\
\hline Strongly Agree & 75 & 56.4 \\
\hline Agree & 50 & 37.6 \\
\hline Strongly Disagree & 7 & 5.3 \\
\hline Disagree & 1 & 0.7 \\
\hline Total & 133 & 100.0 \\
\hline Variable & Frequency & $(\%)$ \\
\hline
\end{tabular}




\begin{tabular}{|c|c|c|}
\hline If other State Govts. adopts OYES initiative, unemployment will be reduced in Nigeria & & \\
\hline Strongly Agree & 61 & 46.9 \\
\hline Agree & 60 & 46.2 \\
\hline Strongly Disagree & 4 & 3.1 \\
\hline Disagree & 4 & 3.1 \\
\hline Undecided & 1 & 0.7 \\
\hline Total & 130 & 100.0 \\
\hline OYES has significantly led to creation of more jobs and reduced the rate of youth's \\
unemployment. & & \\
\hline Strongly Agree & 50 & 38.2 \\
\hline Agree & 60 & 45.8 \\
\hline Strongly Disagree & 10 & 7.6 \\
\hline Disagree & 8 & 6.1 \\
\hline Undecided & 3 & 2.3 \\
\hline Total & 131 & 100.0 \\
\hline Agree & & \\
\hline Strongly Disagree & 4 & 3.1 \\
\hline Disagree & 6 & 4.7 \\
\hline Undecided & 68 & 53.1 \\
\hline Total & 50 & 39.1 \\
\hline Youths have acquired specialized skill via OYES or the improvement of their capacity & 128 & 100.0 \\
\hline
\end{tabular}

(Source: Field Survey, 2013)

Table 2 shows the percentage distribution of respondents and OYES building capacity in Osun State. The data show that none of the respondents strongly agreed that OYES builds youths capacity building in the state and five (5\%) percent of the respondents agreed OYES builds the capacity of youths. Thirteen percent $(13 \%)$ of the respondents strongly disagreed it, more than two out of five of the respondents, representing (43.8\%) disagreed OYES builds youth's capacity. Thirty-eight percent (38\%) of the respondents were indifferent. To ascertain if the implementation of OYES was flawed with challenges the results show that more than half of the respondents, representing (56\%) strongly agreed that the implementation of the scheme was as flawed with challenges across the state. A substantial proportion of the respondents, representing (38\%) agreed that implementation of the scheme was flawed with challenges across the state, however, a small proportion of the respondents, representing (5\%) strongly disagreed it and of the respondents, representing (0.7\%) did not take any side.

Apart from that, a sizeable proportion of the respondents, representing (47\%) believed that unemployment would be drastically reduced if other state governments can adopt a related programme in Nigeria. Forty-six percent (46\%) of the respondents agreed that a similar programme by Federal government will curtail unemployment among the youth. However, small proportion of the respondents, representing (3\%) strongly disagreed while an infinitesimal proportion of the respondents, representing $(0.7 \%)$ did not take a side.

Furthermore, a sizeable proportion of the respondents, representing (38\%) strongly agreed OYES since inception has reduced youth's unemployment in Osun State. While forty-five percent (45\%) of the respondents agreed on that too. Seven percent (7\%) of the respondents strongly disagreed that OYES has reduced youth's unemployment in the state and a handful of (6\%) of the respondents also disagreed this fact, while about $2 \%$ of the respondents are undecided.

Finally, that data show that a handful of the respondents strongly agreed that OYES enhanced specialized skill (3\%); less than one out of 20 of the respondents strongly disagreed (4.7\%); a substantial percentage (523\%) disagreed OYES does not equip youths with specialized skills. And 39\% did not take a side on whether OYES enhance specialized skills or not.

\section{Bivariate Analysis and Hypotheses Testing}

The bivariate analysis measures the relationship between age, an important demographic variable and OYES policy in generating youth employment, evaluates the performance of OYES programme and reduction of unemployment among youths, and the impact of OYES on capacity building of youths in the state. The explanatory variables are OYES policies, socioeconomic and demographic variables while the dependent variable are the evaluation of performance of OYES based on cadets' knowledge on job creation and knowledge on capacity building. The dependent variables are 
categorized into three assessment of knowledge - based such high, average and low. The relationship test was carried out using chi-square test because variable are categorical. The test statistics are presented below.

\section{Hypothesis 1}

"There is no relationship between the implementation of OYES policy and reduction in youth's unemployment in Osun State". This intends to show if there is any relationship between OYES policy, reduction of unemployment and empowerment of youths. This is represented and tested in the table below.

Table 3: Bivariate Relationship between OYES and job creation and Assessment of OYES performance by the respondents

\begin{tabular}{|l|c|c|c|c|}
\hline Variable & \multicolumn{4}{|c|}{ Knowledge-based capacity building } \\
\hline OYES creates jobs and empowers the youth & Low & Average & High & Total \\
\hline Strongly disagree & $0(0.0 \%)$ & $2(66.7 \%)$ & $1(33.3 \%)$ & $3(100.0 \%)$ \\
\hline Disagree & $1(2.4 \%)$ & $35(85.4 \%)$ & $5(52.2 \%)$ & $41(100.0 \%)$ \\
\hline Undecided & $22(24.4 \%)$ & $56(62.2 \%)$ & $12(13.3 \%)$ & $90(100.0 \%)$ \\
\hline Total & $23(17.2 \%)$ & $93(69.4 \%)$ & $18(13.4 \%)$ & $134(100.0)$ \\
\hline
\end{tabular}

$X^{2}=11.58, p=0.02$

(Source: field survey, 2013)

Table 4 shows the relationship between OYES programme effectiveness to reduce unemployment and empowerment of youths and knowledge of cadet members on its capacity building. The results show that none of the respondents strongly disagreed that OYES generates employment and empowers the youth but had low knowledge of its capacity building of beneficiaries, a substantial proportion of the respondents, representing (66.7\%) strongly disagreed that OYES reduces unemployment but reported it builds capacity of cadet members on the average and more than one-third of the respondents, representing (33.3\%) who strongly disagreed OYES reduces unemployment had high knowledge of OYES promoting capacity of cadet members. In addition, a handful of the respondents, representing (2.4\%) disagreed OYES programme reduces unemployment but had low knowledge of it building youth's capacity. A large chunk of the respondents, representing (85.4\%) disagreed that OYES programme reduces unemployment but had average knowledge of it building the capacity of youths more than one-tenth of the respondents, representing (12.2\%) who disagreed OYES programme reduces unemployment had high knowledge of the OYES programme enhancing youth's capacity. Lastly, almost one-fourth of the respondents are non-committal on OYES programme reducing unemployment but had low knowledge of it building youth's capacity, a substantial percentage (62.2\%) of the respondents who are indifferent on OYES reducing youth's unemployment reported it builds youth's capacity on the average. Thirteen percent (13\%) of the respondents who did not take a side on whether OYES programme reduce youth's unemployment had high knowledge of OYES programme in building youth's capacity.

The decision rule stipulated that if the $p$-value is $(p<0.05)$ we should reject null hypothesis and accept the alternative hypothesis. This therefore means that the null hypothesis is rejected, since the critical limit $p$-value $(0.02)$ is less than ( $p$ - value 0.05 ) (see table 3). Therefore, this can be interpreted to mean that OYES policy has been able to reduced unemployment rate and eventually empowered the youths.

\section{Hypothesis 2}

"There is no significant relationship between implementation of OYES and youth capacity building in Osun State.". This hypothesis seeks to measure if the capacity building of the youth has been improved through implementation of OYES in the state. It intended to test if improvement in capacity building of the youth depends on implementation of OYES in the state. This is represented and tested in the table below. 
Table 4: Bivariate Relationship between Youth Capacity Building and implementation of OYES scheme

\begin{tabular}{|l|c|c|c|c|}
\hline $\begin{array}{l}\text { Implementation of OYES, improves } \\
\text { youth's capacity }\end{array}$ & \multicolumn{4}{|c|}{ Knowledge of OYES members on Youth's capacity building and skills } \\
\hline & Low & Average & High & Total \\
\hline Strongly Agree & $0(0.0 \%)$ & $1(100.0 \%)$ & $0(0.0 \%)$ & $1(100.0 \%)$ \\
\hline Agree & $0(0.0 \%)$ & $6(100.0 \%)$ & $0(0.0 \%)$ & $6(100.0 \%)$ \\
\hline Strongly Disagree & $0(0.0 \%)$ & $4(100.0 \%)$ & $0 .(0.0 \%)$ & $4(100.0 \%)$ \\
\hline Disagree & $11(18.6 \%)$ & $39(66.1 \%)$ & $9(15.3 \%)$ & $54(100.0 \%)$ \\
\hline Undecided & $12(18.8 \%)$ & $43(67.2 \%)$ & $9(14.0 \%)$ & $64(100.0 \%)$ \\
\hline Total & $23(17.2 \%)$ & $93(69.4 \%)$ & $18(13.4 \%)$ & $134(100.0 \%)$ \\
\hline
\end{tabular}

$X^{2}=5.32, p=0.72$

(Source: Field Survey, 2013)

Table 4 shows relationship between youth capacity building, skills acquisition and implementation of OYES scheme. The results shows that none of the respondents who strongly agreed that implementation of OYES improves youth capacity had low knowledge of its capacity building influence; all the respondents who strongly agreed that implementation of OYES improves youth capacity had average knowledge of its capacity building influence. All the respondents who agreed that implementation of OYES improves youth capacity had average knowledge of its capacity building impact. In addition, more than two - third of the respondents', representing (66.1\%) who disagreed that implementation of OYES improves youth capacity had average knowledge of its capacity building influence. Less than one-fifth of the respondents' representing (18.6\%) who disagreed that implementation of OYES improves youth capacity had low knowledge of its capacity building impact. Fifteen percent (15\%) of the respondents who had high knowledge of OYES capacity building impact disagreed that implementation of OYES improves youth capacity.

Finally, a substantial proportion of the respondents' representing (67\%) who had average knowledge of OYES programmes capacity building influence are indifference about the implementation of OYES improves youth capacity. Fourteen percent (14\%) of the respondents who had high knowledge of OYES capacity building influence did not take a side that implementation of OYES improves youth capacity and eighteen percent (18\%) who had low knowledge of OYES programme capacity building impact are non-committal that implementation of OYES improves youth capacity.

The results show that OYES, being a skill acquisition programme is not statistically significant with youth capacity building. Therefore, this can be interpreted to mean that according to the above test of hypothesis the implementation of OYES has equipped youths with skills but youth capacity building is still not improved in the state. This therefore means that the null hypothesis is accepted, since the critical limit $p$-value $(0.72)$ is greater than ( $p$-value 0.05$)$

\section{Analysis of Interviews}

Personal interviews were held with three OYES instructors from the 3 districts representing Osun State on effect of OYES on job creation and capacity building of the youth in Osun State. On effect of OYES on job creation and youths empowerment, for the three respondents, the introduction of OYES in Osun State has led to creation of more jobs which in turn reduced the rate of youth unemployment. All of them, responded in the affirmative that since OYES scheme was introduced, jobs have been created in sectors like education, public works, agriculture, health ( $O^{\prime}$ ambulance) and environmental. On this issue, the response of Mr. Adedayo Ajayi, an OYES instructor, llesa was particularly revealing. For him ${ }^{1}$

OYES though has its shortcomings but the scheme has been able to create low income jobs like tailoring job, block making job, teaching job, ICT (phone repairer job, electronic gadgets repairer job, laptop repairer job).The state government has been able to create jobs for OYES cadets who are into tailoring as they are the one responsible for sewing all the school uniforms for pupils and students in public schools since their uniforms are same.

On youths capacity building, respondents' response to this question show that all of them strongly agreed that OYES scheme only provides few youths with skills in ICTs, block moulding and tailoring while majority of the youth are deployed to community service and rural development which only require physical strength of the youths, in this case, the respondents believed that the youths are only used to serve the state and being paid a stipend for their service. Oyebode, an OYES coordinator, Osun Central, contended that this cannot really enhance the capacity building of youths in the 
state as they are used to do all sorts of unskilled menial job². In the same vein, Oladapo contended that in the scheme, graduates are employed to do menial jobs, such as clearing of debris on roads and cutting of grasses. It is said that the jobs are a sharp contrast from their area of training and assumed expertise; it is un-dignifying, non-productive and wasteful (Oladapo, 2012).

\section{Discussion of Findings}

The objectives and hypotheses earlier stated in this paper were analysed and tested with data collected from the field through interview and questionnaire administered on key respondents. Having analysed objectives of the study and tested the hypotheses, the first null hypothesis was rejected while the second was accepted, it is imperative to discuss the findings further. The first objective and hypothesis was confirmed by respondents' responses gathered from both the qualitative and quantitative data "that the introduction of OYES policy in Osun State has significantly led to more jobs creation which in turn slightly reduced unemployment rate and empowers youths in Osun State". Results from the quantitative data shows that $84 \%$ of the respondents were of the view that more jobs were created since the introduction of OYES in Osun State (see table 2). This result was corroborated with the responses of other key informants during the interview sessions, where majority of them contended that the introduction of OYES policy, has been very helpful in creation of jobs, reduction of youth unemployment and empowerment in Osun State.

The second hypothesis that "There is no significant relationship between implementation of OYES and youth capacity building in Osun State." was accepted and confirmed. For the quantitative data, result shows that $57 \%$ of the respondents were of the view that OYES, though a skill acquisition programme, but was not statistically significant with youth capacity building in the state and $38 \%$ of the respondents are undecided or take no side (see table 2). Therefore, this can be interpreted to mean that the formulation and implementation of OYES though has equipped some beneficiaries with skills but does not necessarily translates to improving or building their capacity (see table 2).

For the qualitative data, result from content analysis shows that all the respondents agreed that though OYES is a skill acquisition programme but it focused more on unskilled menial labour while only few beneficiaries of the scheme have enjoyed skills acquisition programme, a whole lot of them are deployed to doing menial jobs of sweeping major streets, cutting grasses and other energy demanding works that cannot improve their capacity. The three key respondents believed that the reason for low capacity building of youths is that there are few available job exit routes for the beneficiaries to consolidate the skills they have acquired. For instance, after the mandatory two years of OYES programme, those cadets who are not fixed into any job position are left idle while they roamed the street for jobs. It was reported that their skills gradually fade out because of loss of touch with adequate capacity building facilities ${ }^{3}$. Apart from findings from these two hypotheses, other findings include:

One, the study discovered that the scheme (OYES) has been helpful in curbing of crimes and insecurity in the state. This finding was corroborated by Iroubuisi (2013) when he argued that: "Our findings have also revealed a sharp decrease in crime rate in the state as a result of the engagement of youth through the OYES scheme of the government." Secondly, it was discovered that implementation of the scheme was not free from some challenges like poor funding, lack of adequate provision of law backing it, non-certification of beneficiaries after the programme, misplaced priority and limited exit job routes to accommodate the beneficiaries, lack of private-government partnership and undue influence of ruling party members over placement of beneficiaries on available job vacancies.

\section{Policy Recommendations}

At the heart of the Osun State Youth Empowerment Scheme (OYES), as the study has rightly pointed out, is the attempt to create more jobs, eschew unemployment, poverty and enhance youth capacity building in Osun State. Understandably, there are provisions which tend to guarantee the empowerment of youths. But there is no legally backed affirmative law or Act to back the OYES policy in Osun State. Conceptually, the Osun State House Assembly over sight functions can be broadened to include provisions, which will encapsulate the OYES policy. This could be by way of a clause stipulating a minimum number of OYES cadets for recruitment in certain public offices. However, some are wont to point to problems that may be associated with this constitutional/legal provisions.

The fact of rigidity of constitutional provisions is not lost on this study. To constitutionalize a guaranteed minimum number of OYES cadets for job placement according to skills acquired and qualifications in certain public offices in the public sector may make such provision rigid. Rigidity in itself is not necessarily evil. The need for strict adherence to certain provisions may justify the rigidisation of such provisions.

Furthermore, it may also be argued that to set aside a certain minimum number of OYES cadets' for recruitment 
into public service may imply sacrificing merit for mediocrity. These and some other problems are likely to be thrown up. It is important to point out emphatically, that the whole idea for suggesting a legally or constitutionally guaranteed minimum number of OYES cadets for job placement in public service is not to relegate "merit system" to the background. Rather, it is meant to reduce youth unemployment in the state.

To this end, such a provision could merely provide for youth recruitment in, say, every public school, waste management offices, state enterprises, government offices and local government councils. In this way, even in government offices and local governments' secretariats where favouritism and spoilt system in job recruitment is the order of the day, such provision will ensure the demise of such practices.

In addition, it will facilitate the acceptance, by the generality of people, that the youth can be very useful in the development of the state. This provision can also be made transitional in which case it will operate for a specified period of time. These strategies will promote youth empowerment and recruitment into the public service by formulating and implementing appropriate empowerment schemes and policies which will enhance societal acceptability of the placement of the OYES cadets into the state civil service.

It is also imperative to state that while the suggestion for the broadening of the over sight functions of the Osun State House of Assembly to promote youth entrant into the civil service after completion of the OYES programme remains a valid and feasible option, promoting the recruitment of the youth into the state public service in a rapid and effective manner demands a multidimensional approach. In addition to the OYES policy, (greater) emphasis should be laid on discouraging, by a combination of legislation and education, those beliefs and practices that are discriminatory against OYES cadets in their selection for the programme and final placement in public service and Osun State Government should ensure that there is award of certificates to beneficiaries of the scheme after the two years mandatory programme, this, will go a long way in adding some value and sense of belonging to the beneficiaries.

The monthly allowance being paid to beneficiaries should be reviewed to boost the morale of the cadets towards efficient contribution to their work. The government should seek for the partnership of the private sector for financing and training of the beneficiaries, this could be by reaching an agreement with the private firms that operates within Osun State to accept the posting of some beneficiaries in form of Industrial training (IT).

\section{Conclusion}

All states, including Osun State in Nigeria were actually not devoid of how to design and formulate loud-mouthed policies on youth empowerment, but the implementation of such policies or schemes have always been done badly. But Osun State since 2010 has formulated and implemented policy on youth empowerment to serve as vehicle through which youths in the state can be empowered and gain job access into the state civil service. The degree of youth empowerment policies or schemes, however, differed from one state to another. The negligence on the part of some governments to harness youth potentials in their respective state have had considerable impact on violent militancy, civil unrest and terrorist insurgency masterminded by youths in the political sphere tilting the pendulum in outrageous disfavour to the youth.

Against the background of this, the study examined a policy analysis of Osun State Empowerment Scheme (OYES) in promoting creation of more jobs and youth empowerment in Osun State. It is the contention of this study that this scheme (OYES) can be helpful in this direction. Nevertheless, some challenges are discovered in its implementation and solutions proffered to them. Finally, the study have also argued that for an effective and quick move towards youth empowerment and reduction of youth unemployment via OYES in Osun State a multi-pronged approach requiring a combination of factors need to be adopted.

To this end, emphasis should be laid on, inter alia, creating in people and government mind a favourable attitude towards formulating and implementing youth empowerment policy or scheme and discouraging practices that are against harmonisation of youth potentials particularly those that are antithetical to youth empowerment and their recruitment into public service. The study add that empowering the youth through appropriate policies and schemes such that they can be gainfully be recruited into public service requires concerted and sustained effort. Considerable successes in a gleam of an eye require some enduring time and understanding.

\section{Notes}

Mr. Adedayo Ajayi, an OYES instructor, from Osun East

B. G Oyebode, OYES coordinator, from Osun West

A. M Adelani, OYES coordinator, from Osun Central 


\section{References}

Agary, T.K. (2010, November, 24). Youth Empowerment: Panacea for peace and development. Paper presented at the Ajasin Foundation Colloquium Retrieved from "http://www.statcounter.com/" target="_blank"><img class="statcounter" src="http://c39 .statcounter.com/3433977/0/2feb9e38/1/" alt="blog stats" ></a ></div> Forum | Social Network | Jobs | General Topics | Privacy

Ayinde, O.E. (2008). "Empirical Analysis of Agricultural Growth and Unemployment in Nigeria". African Journal of Agricultural Research, $3(7), 465-468$.

Azikwe, .U. (2006a). Standard in Tertiary Education: Capacity Building and Sustainable Development in Nigeria. A lead paper represented at the Annual Conference at the Faculty of Education, Nnamdi Azikwe University, Awka, Anambra State.

Carter, S., \& Wilton, W. (2006). "Don't blame the entrepreneur, blame the government: The centrality of the government in enterprise development; lessons from enterprise failure in Zimbabwe". Journal of Enterprising Culture, 14(1):65-84.

Ifaturoti, F. (2013, 16 $6^{\text {th }}$ November). Assessing Osun Youth Empowerment Scheme. Osun News. Retrieved from (http://www.osun. gov.ng/ ).Accessed on $16^{\text {th }}$ November, 2013.

Iroubuisi, N. A (2013). Low crime in Osun linked to Aregbesola's youth's empowerment schemes. Course 22 seminar held at Sani Abacha Hall of the National Defence College Abuja. Retrieved from https:/wwww.facebook. com/offsite_event.php?id=600876 5000187\&amp;value=0\&amp;currency=USD" I> . Accessed 28th November, 2013

Oluremi H.A, \& Agboola, G.M. (2011). "Environmental Factors and Entrepreneurship Development in Nigeria". Journal of Sustainable Development in Africa Vol. 13, No.4, Clarion University of Pennsylvania, Clarion, Pennsylvania 